\title{
ANALISIS PENGARUH PERUBAHAN TUTUPAN LAHAN TERHADAP HIDROLISIS DAS PAMUKKULU SULAWESI SELATAN
}

\section{(Analysis of Influence of Land Closure Change on Pamukkulu Watershed Hydrolysis in South Sulawesi)}

\author{
Andi Rasti Serastiwati ${ }^{1)}$, St.Subaedah ${ }^{2)}$, Netty Syam $^{2)}$ \\ ${ }^{1)}$ Mahasiswa Program Studi Megister Agroekoteknologi, Program Pascasarjana UMI \\ ${ }^{2)}$ Dosen Program Studi Megister Agroekoteknologi, , Program Pascasarjana UI \\ ${ }^{1)}$ Email : criwiz24@yahoo.co.id \\ ${ }^{2)}$ Email : st.subaedah@umi.ac.id \\ ${ }^{2)}$ Email : nettysyam@gmail.com
}

\begin{abstract}
The Pamukkulu watershed is one of the Jeneberang-Kelara Sub-watersheds, which is one of the 108 Priority Watersheds in Indonesia determined based on the 2017 Ministry of Environment and Forestry Performance Report which is prioritized as a location for Forest and Land Rehabilitation activities. The purpose of this study was to analyze changes in land cover in the Pamukkulu watershed in 2008 and 2017, the effect of land cover changes in the Pamukkulu watershed on fluctuations in major river flows and analyze the health level of the Pamukkulu watershed based on analysis of major river discharge and changes in land cover. The study was conducted from February to April 2018. Data collection was carried out by taking secondary data in the form of land cover data in 2008 and 2017, climate data, and Pamukkulu River discharge data. The results showed that based on the results of the analysis of the Land Cover Index (IPL), the condition of Pamukkulu watershed land cover in 2008 was at $19.38 \%$ and $16.96 \%$ in 2017 so that it was categorized as bad. The results of the hydrological analysis (river water discharge) on the River Regime Coefficient in 2008 were 125 and in 2017 amounted to 119.6 so that the KRS is also categorized as bad. While the results of the analysis of the Variant Coefficient $(C V)$ in 2008 amounted to 144.90\% and in 2017 amounted to $87.5 \%$ then the CV was categorized as poor. Based on the analysis of the value of the Land Cover Index, River Regime Coefficient and River Regime Coefficient in the Pamukkulu Watershed in 2008 and 2017 which are in the poor category, the performance of the Pamukkulu Watershed is in the poor category.
\end{abstract}

Keywords : Ecological Changes; Map Overlays; Discharge Fluctuations; and The Jeneberang River

\section{PENDAHULUAN}

Pengelolaan sumberdaya alam dan lingkungan hidup yang tidak dilakukan sesuai dengan daya dukungnya dapat menimbulkan krisis pangan, air, energi dan lingkungan. Dalam era otonomi daerah, pengelolaan lingkungan hidup selain mengacu pada Undang-undang Nomor 32 tahun 2009 tentang Perlindungan dan Pengelolaan
Lingkungan Hidup, juga pada Undangundang Nomor 23 tahun 2014 tentang Pemerintahan Daerah. Selain itu, Undangundang Nomor 32 Tahun 2009 tentang Perlindungan dan Pengelolaan Lingkungan Hidup menetapkan kewajiban pemerintah untuk menerapkan sustainable development sebagai solusi untuk memperbaiki kerusakan lingkungan tanpa 
mengorbankan kebutuhan pembangunan ekonomi dan keadilan sosial.

Secara ekologis, DAS sebagai suatu sistem kompleks sangat besar peranannya dalam hal tata guna air, dimulai dari terjadinya presipitasi sebagai input, selanjutnya berlangsungnya prosesproses dalam sistem DAS sampai kepada terbentuknya debit sungai (stream flow) sebagai outputnya. Fenomena tersebut ditentukan baik oleh karakteristik alam DAS (tanah, iklim, vegetasi, dll) (natural faktor), maupun kegiatan manusia (anthropogenic factor). Keseluruhan karakteristik dan proses dalam sistem tersebut akan sangat mempengaruhi kondisi keberlanjutan (sustainability) DAS secara keseluruhan (Baja et al, 2012).

DAS Pamukkulu merupakan salah satu Sub DAS Jeneberang-Kelara yang merupakan salah satu dari 108 DAS Prioritas di Indonesia berdasarkan Laporan Kinerja Kementerian Lingkungan Hidupdan Kehutanan Tahun 2017 yang ditetapkan untuk diprioritaskan sebagai lokasi prioritas kegiatan Rehabilitasi Hutan dan Lahan, termasuk di dalamnya penyelenggaraan reboisasi, penghijauan, dan konservasi tanah dan air, baik vegetatif, agronomis, struktural, maupun manajemen. DAS Pamukkulu yang melintasi tiga kabupaten yakni Kabupaten Gowa, Kabupaten Takalar, dan Kabupaten Jeneponto dan terbagi atas empat Sub DAS yakni Binanga Dingau, Binanga Lantang, Binanga Pungagi, dan Binanga Bulrea.

Berdasarkan data sekunder yang diperoleh dari Dinas Sumber Daya Air, Cipta Karya dan Tata Ruang Provinsi Sulawesi Selatan Tahun 2017 di peroleh gambaran bahwa terjadi fluktuasi tinggi muka air harian di sungai utama yakni Sungai Pamukkulu serta data terjadinya luapan air sungai / banjir yang di tunjukkan oleh tinggi muka air sungai yang mencapai 4-5 m sedangkan di musim kemarau hanya $0,11 \mathrm{~m}$. Hal tersebut memberi gambaran bahwa tingkat kesehatan DAS / kinerja DAS Pamukkulu mengalami gangguan.

Oleh karena itu di rasa perlu untuk melaksanakan kegiatan penelitian untuk mengetahui perubahan apa yang terjadi di wilayah DAS bersangkutan demi kepentingan perencanaan tindakan konservasi yang akan dilaksanakan sehingga disesuaikan dengan kondisi lapangan sebenarnya dan tidak hanya sekedar menghabiskan anggaran 
Pemerintah tanpa membawa dampak debit sungai (Tata Air/Hidrologi). Dengan positif. mengetahui fungsi hidrologi suatu DAS maka akan diketahui tingkat kesehatan

\section{METODE PENELITIAN}

Penelitian ini dilaksanakan di DAS Pamukkulu (Kabupaten Gowa, Kabupaten Takalar, dan Kabupaten Jeneponto). Tahapan penelitian antara lain dilakukan (1) Analisis perubahan penutupan lahan dengan cara studi literatur, pengumpulan data, overlay peta dan citra dan survey lapangan. (2) Penentuan indeks penutupan lahan (IPL) yang dihitung melalui perbandingan antara luas lahan dengan vegetasi permanen dengan luas keseluruhan wilayah DAS. (3). Analisis debit sungai berupa Koefisien Limpasan Permukaan (C) yang dihitung dengan menggunakan Curve Number $(\mathrm{CN})$, Koefisien Regim Sungai (KRS), dan Koefisien Varian (CV). (3) Penentuan tingkat kesehatan DAS yang diukur dari aspek penutupan lahan dengan menggunakan parameter Indeks Penutupan Lahan (IPL) dan pengukuran
DAS.

\section{HASIL DAN PEMBAHASAN}

\section{Perubahan Penutupan Lahan DAS Pamukkulu}

Perubahan penutupan lahan adalah bertambahnya suatu penutupan lahan dari satu sisi penutupan ke penutupan yang lainnya diikuti dengan berkurangnya tipe penutupan lahan yang lain dari suatu waktu ke waktu berikutnya, atau berubahnya fungsi suatu lahan pada kurun waktu yang berbeda (Wahyunto, 2001). Perubahan penutupan lahan pada umumnya dapat diamati dengan menggunakan data spasial dari peta penutupan lahan dari beberapa titik tahun yang berbeda. Data penginderaan jauh seperti citra satelit, radar, dan foto udara yang dilakukan oleh Dirjen Planologi dan Tata Lingkungan, Kementerian Lingkungan Hidup dan Kehutanan. 
Andi Rasti Serastiwati : Analisis Pengaruh Perubahan Tutupan Lahan terhadap Hidrolisis dan

Pamukkulu Sulawesi Selatan

Tabel 1. Perubahan Penutupan Lahan di DAS Pamukkulu

\begin{tabular}{|c|c|c|c|c|c|c|}
\hline No. & Penutupan Lahan (PL) & $\begin{array}{l}\text { Luas (ha) PL } \\
2008\end{array}$ & $\begin{array}{l}\text { Luas (ha) } \\
\text { PL } 2017\end{array}$ & $\begin{array}{l}\text { Persentase } \\
(\%) \\
\text { PL } 2008\end{array}$ & $\begin{array}{l}\text { Persentase } \\
(\%) \text { PL } \\
2017\end{array}$ & $\begin{array}{l}\text { Kondisi } \\
\text { Perubahan } \\
\text { (ha) }\end{array}$ \\
\hline 1 & $\begin{array}{l}\text { Hutan Lahan Kering } \\
\text { Sekunder }\end{array}$ & 1673,56 & 1673,56 & 4,19 & 4,19 & 0,00 \\
\hline 2 & Pemukiman & 0,00 & 905,90 & 0,00 & 2,27 & 905,90 \\
\hline 3 & Pertanian Lahan Kering & 4175,89 & 4706,61 & 10,45 & 11,78 & 530,71 \\
\hline 4 & $\begin{array}{l}\text { Pertanian Lahan Kering } \\
\text { Campur Semak }\end{array}$ & 12131,39 & 10205,22 & 30,37 & 25,55 & $-1926,17$ \\
\hline 5 & Sawah & 14780,20 & 15110,11 & 37,00 & 37,83 & 329,91 \\
\hline 6 & Semak Belukar & 6469,91 & 6565,78 & 16,20 & 16,44 & 95,87 \\
\hline 7 & Tambak & 435,84 & 499,62 & 1,09 & 1,25 & 63,78 \\
\hline 8 & Tubuh Air & 277,52 & 277,52 & 0,69 & 0,69 & 0,00 \\
\hline Tota & & 39944,32 & 39944,32 & 100,00 & 100,00 & - \\
\hline
\end{tabular}

Sumber : Analisis SIG, 2019

Tabel 2. Matriks Perubahan Penutupan Lahan di DAS Pamukkulu

\begin{tabular}{|c|c|c|c|c|c|c|c|c|c|}
\hline \multirow[b]{2}{*}{$\begin{array}{c}\text { Penutupan } \\
\text { Lahan } \\
2008\end{array}$} & \multicolumn{8}{|c|}{ Penutupan Lahan 2017} & \multirow[b]{2}{*}{$\begin{array}{l}\text { Total } \\
\text { Penutupan } \\
\text { Lahan } \\
\text { Tahun } \\
2008 \\
\end{array}$} \\
\hline & $\begin{array}{l}\text { Hutan } \\
\text { Sekunder }\end{array}$ & $\begin{array}{l}\text { Pemu } \\
\text { kiman }\end{array}$ & $\begin{array}{l}\text { Pertanian } \\
\text { Lahan } \\
\text { Kering }\end{array}$ & $\begin{array}{l}\text { Pertanian } \\
\text { Lahan } \\
\text { Kering } \\
\text { Campur } \\
\text { Semak } \\
\end{array}$ & Sawah & $\begin{array}{l}\text { Semak } \\
\text { Belukar }\end{array}$ & Tambak & $\begin{array}{l}\text { Tubuh } \\
\text { Air }\end{array}$ & \\
\hline $\begin{array}{l}\text { Hutan } \\
\text { Sekunder } \\
\text { Pertanian } \\
\text { Lahan }\end{array}$ & 1673,56 & & & & & & & & 1673,56 \\
\hline $\begin{array}{l}\text { Kering } \\
\text { Pertanian } \\
\text { Lahan }\end{array}$ & & & 2408,13 & & 1767,76 & & & & 4175,89 \\
\hline $\begin{array}{l}\text { Kering } \\
\text { Campur } \\
\text { Semak }\end{array}$ & & 306,68 & 723,97 & 9990,37 & 902,27 & 202,11 & 6,01 & & 12131,39 \\
\hline $\begin{array}{l}\text { Sawah } \\
\text { Semk }\end{array}$ & & 596,47 & 1574,51 & 111,38 & 12440,08 & & 57,77 & & 14780,20 \\
\hline Belukar & & 2,76 & & 103,48 & & 6363,67 & & & 6469,91 \\
\hline Tambak & & & & & & & 435,84 & & 435,84 \\
\hline Tubuh Air & & & & & & & & 277,52 & 277,52 \\
\hline Total & 1673,56 & 905,90 & 4706,61 & 10205,22 & 15110,11 & 6565,78 & 499,62 & 277,52 & 39944,32 \\
\hline
\end{tabular}

Sumber : Analisis SIG, 2019

Tabel 1, dan 2 menunjukkan berupa hutan sekunder, dan tubuh air tidak perubahan penutupan lahan seluas mengalami perubahan sejak tahun $2008 \mathrm{di}$ 6.355.15 hektar. Jenis penutupan lahan DAS Pamukkulu. Jenis Penutupan lahan 
pertanian lahan kering campur semak jumlah penduduk yang semakin mengalami perubahan paling besar seluas meningkat sehingga mendorong mereka sekitar 2000 hektar. Pertanian lahan untuk merubah lahan. Tingginya angka kering campur semak terkonversi menjadi kelahiran dan perpindahan penduduk pemukiman, pertanian lahan kering, memberikan pengaruh yang besar pada sawah, semak belukar, dan tambak. Jenis perubahan penggunaan lahan. Perubahan penutupan lahan pemukiman pada tahun lahan (Gambar 1) juga biasa disebabkan 2008 belum ada, mengalami pertambahan adanya kebijaksanaan pemerintah dalam luas sebesar 905,90 hektar pada tahun melaksanakan pembangunan di suatu 2017. Pemukiman terkonversi dari jenis penutupan lahan berupa pertanian lahan kering campur semak, sawah, dan semak belukar. Faktor utama yang mendorong perubahan penggunaan lahan adalah wilayah (Diana, 2008).

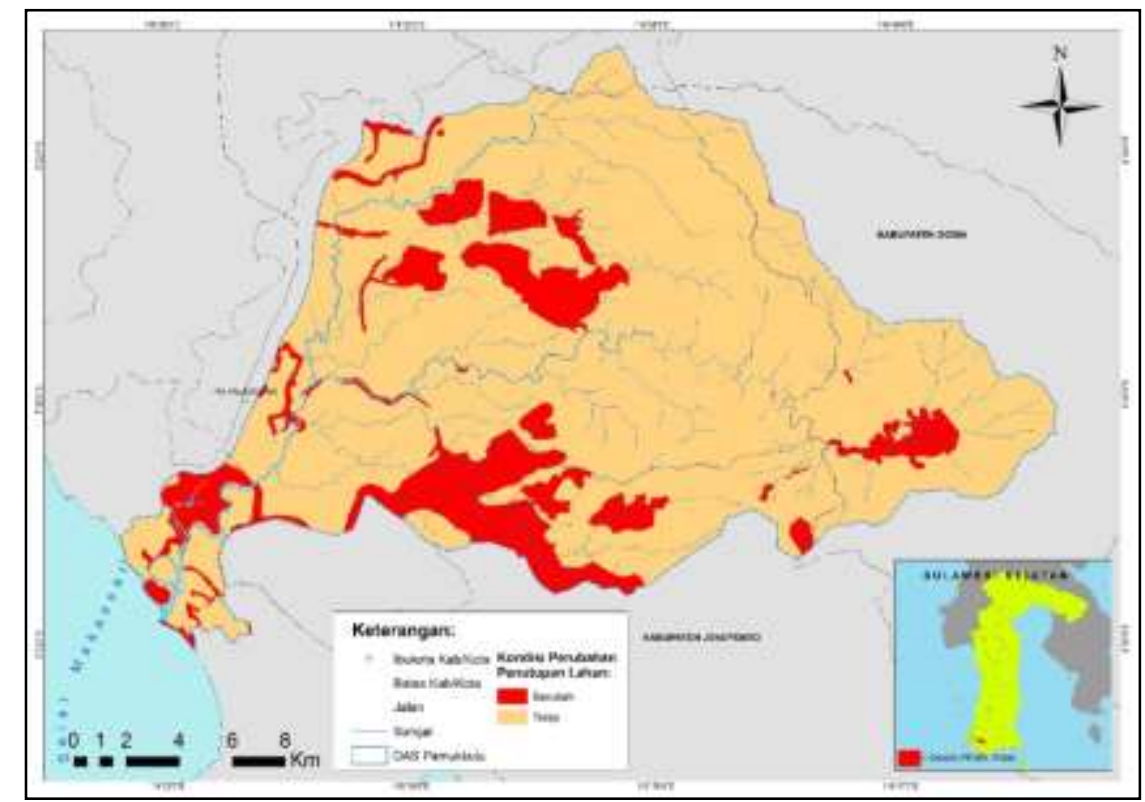

Gambar 1. Peta Perubahan Penutupan Lahan Tahun 2008 - 2017 di DAS Pamukkulu

Penutupan lahan berasal dari data Hidup dan Kehutanan. Penutupan Lahan sekunder Dirjen Planologi dan Tata berupa hutan sekunder tidak mengalami Lingkungan, Kementerian Lingkungan perubahan selama tahun 2008 sampai 
2017. Ada beberapa hal yang lereng yang sangat curah yang tidak menyebabkan tidak terjadi perubahan mudah diakses.

mulai dari regulasi, infrastruktur, dan kondisi alam. Secara regulasi hutan sekunder berada pada fungsi Kawasan hutan lindung yang sangat dijaga

\section{Indeks Penutupan Lahan DAS} Pamukkulu beradaannya sebagai penyangga Penutupan indeks vegetasi lahan kehidupan untuk mengatur tata air, bervegetasi permanen (LVP) dan luas mencegah banjir, dan memelihara DAS yang terdapat pada peta penutupan kesuburan tanah (Gambar 8). Selanjutnya lahan (land use). Luas vegetasi permanen faktor lain adalah infrastruktur berupa diperoleh dari peta penutupan lahan aktual jaringan jalan. Pada hutan sekunder tidak dan atau analisis foto udara atau citra dilalui oleh jaringan jalan, sehingga tidak satelit dari Dirjen Planologi dan Tata ada akses masyrakat dalam mengkonversi Lingkungan, Kementerian Lingkungan hutan tersebut. Terakhir adalah faktor Hidup, dan Kehutanan. Vegetasi alam berupa ketinggian termasuk kondisi permanen yang dimaksudkan adalah kemringan lereng. Bahwa hutan tersebut tanaman tahunan seperti vegetasi hutan berada ketinggian tertinggi di DAS dan atau kebun yang dapat berfungsi Pamukkulu yang memiliki kemiringan lindung dan atau konservasi.

Tabel 3. Indeks Penutupan Lahan DAS Pamukkulu Tahun 2008 dan Tahun 2017

\begin{tabular}{|r|l|r|r|r|r|}
\hline \multirow{2}{*}{ No } & \multirow{2}{*}{ Penutupan Lahan } & \multicolumn{2}{|c|}{ Penutupan Lahan 2008} & \multicolumn{2}{c|}{ Penutupan Lahan 2017} \\
\cline { 3 - 6 } & & Luas (Ha) PL 2008 & Persentase (\%) & Luas (Ha) PL 2017 & Persentase (\%) \\
\hline 1 & Hutan Sekunder & 1673.56 & 4.19 & 1673.56 & 4.19 \\
\hline 2 & Kebun & 6065.70 & 15.19 & 5614.15 & 12.77 \\
\hline \multicolumn{2}{|c|}{ Jumlah Vegetasi Permanen } & 7739.26 & 19.38 & 7287.71 & 16.96 \\
\hline Kelas Nilai IPL & & $<30 \%$ & & \multicolumn{1}{c|}{ Jelek } \\
\hline
\end{tabular}

Sumber : Analisis GIS, 2019

Berdasarkan penutupan lahan pada penutupan berupa hutan sekunder, dan Tabel 5, 6, dan 7 menunjukkan jenis pertanian lahan kering campur semak 
yang tergolong vegetasi permanen.

Namun jenis penutupan lahan pertanian lahan kering campur semak hanya sebagain luasannya yang tergolong vegetasi permanen yaitu kebun. Adapun luas vegetasi permanen yaitu seluas 6776,17, sehingga nilai IPL DAS Pamukkulu sebesar 17 persen. Berdasarkan standar evaluasi, IPL DAS Pamukkulu tergolong jelek.

\section{Debit Sungai DAS Pamukkulu}

\section{Koefisien Aliran Permukaan}

Pada metode SCS-CN Salah satu parameter penentuan volume air permukaan adalah curah hujan. Curah hujan DAS Pamukkulu menggunakan data curah hujan pada tahun 2017. Data curah hujan yang digunakan berupa curah hujan bulanan dari stasiun curah hujanBalai
Besar Sungai Wilayah

(BBSW)

Pompengan Jeneberang yang ada disekitar DAS Pamukkulu. DAS Pamukkulu mencakup stasiun curah hujan Malolo, Pamukkulu, Malakaji, dan bangkala Barat, yang selanjutnya dari titik kordinat stasiun tersebut dibuat data spasial curah hujan berdasarkan metode polygon thiessen yang meruapakan area yang dipengaruhi oleh titik (stasiun cuaca). Poligon ini merupakan pendekatan terhadap informasi titik yang diperluas (titik menjadi poligon). Proses pembuatan peta curah hujan dari metode thiessen dilakukan dengan menggunakan analisis software sistem informasi geografis. Adapun data curah hujan DAS Pamukkulu disajikan pada Tabel 4.

Tabel 4. Data Curah Hujan DAS Pamukkulu

\begin{tabular}{|l|c|c|c|c|r|}
\hline \multirow{2}{*}{ Bulan (mm) } & \multicolumn{4}{|c|}{ Stasiun 2017 } & Jumlah \\
\cline { 2 - 6 } & Malakaji & Malolo & Pamukkulu & Bangkala & Rata-rata \\
\hline Januari & 198 & 482 & 608 & 165 & $\mathbf{3 6 3}$ \\
\hline Februari & 234 & 563 & 772 & 85 & 414 \\
\hline Maret & 160 & 405 & 397 & 160 & 281 \\
\hline April & 167 & 227 & 341 & 92 & 207 \\
\hline Mei & 122 & 75 & 90 & 55 & 86 \\
\hline Juni & 112 & 127 & 209 & 32 & 120 \\
\hline Juli & 100 & 141 & 119 & 37 & 99 \\
\hline Agustus & 25 & 68 & 44 & 10 & 37 \\
\hline September & 10 & 80 & 29 & 47 & 42 \\
\hline Oktober & 178 & 103 & 75 & 77 & 108 \\
\hline November & 222 & 322 & 260 & 126 & 233 \\
\hline Desember & 323 & 638 & 653 & 242 & 464 \\
\hline
\end{tabular}

Sumber : BBWS Pompengan Jeneberang, 2019 
Tabel diatas menunjukkan dari secara fisik mempengaruhi besarnya aliran empat stasiun hujan yang ada dan atau permukaan air pada suatu lahan. Hidrologi disekitar DAS Pamukkulu, maka tanah ditentukan berdasarkan peta detail diperoleh data curah hujan rata-rata DAS tanah atau landsystem RePPProt tahun Pamukkulu setiap bulannya pada tahun 1987 kemudian diklasifisikan berdasarkan 2017. Curah hujan pada stasiun sifat fisik tanah. Klasifikasi kompleks Pamukkulu merupakan curah hujan penutup tanah SCS terdiri atas tiga faktor tertinggi pada DAS Pamukkulu. yaitu kedalaman tanah, tekstur, dan Sedangkan stasiun curah hujan Bangkala keadaan hidrologi (drainase). Adapun yang terletak di Kabupaten Jeneponto kelompok hidrologi tanah di DAS merupakan curah hujan yang terendah Pamukkulu disajikan pada Tabel 5 pada DAS Pamukkulu. Hidrologi tanah

Tabel 5. Hidrologi Tanah DAS Pamukkulu

\begin{tabular}{llrrr}
\hline No. & Jenis Tanah & Hidrologi Tanah & Luas (ha) & Persentase (\%) \\
\hline \hline 1 & Dystropepts & $\mathrm{A}$ & 16165,92 & \\
2 & Haplustults & $\mathrm{C}$ & 9052,27 & 40,47 \\
3 & Tropaquepts & $\mathrm{C}$ & 6164,08 & 22,66 \\
4 & Ustipsamments & $\mathrm{A}$ & 638,31 & 15,43 \\
5 & Ustropepts & $\mathrm{A}$ & 7923,74 & 1,60 \\
\hline \hline & & & 39944,32 & 19,84 \\
\hline
\end{tabular}

Sumber : RePPProt, 1987

Berdasarkan Tabel 5 menunjukkan jenis tanah dan hidrologi tanah pada DAS Pamukkulu. Ada lima jenis tanah dan dua kelompok hidrologi tanah di DAS Pamukkulu Jenis tanah di didominasi oleh jenis tanah Dystropepts dengan luas 16.165,92 dengan persentase 40,47 persen dari luas DAS Pamukkulu. Sedangkan hidrologi tanah didominasi oleh hidrologi tanah A dengan persentase 80 persen lebih dari luas DAS Pamukkulu.
Penentuan bilangan curve number (CN) di DAS Pamukkulu secara SCS CN dengan menggunakan metode System Informasi Geografis (SIG) akan lebih mudah untuk mengelompokkan nilai bilangan curva number .Nilai Curve Number diperoleh dari masing-masing hidrologi tanah terhadap penutupan lahan kecuali jenis penutupan berupa tubuh air.curve number akan digunakan dalam persamaan fungsi untuk melihat respon 
penahan air potensial tahun 2017 seperti penutupan lahan nilai perhitungan curve pada hitungan dibawah.Adapun luas number tahun 2017 DAS Pamukkulu Curve number hidrologi tanah terhadap disajikan pada Tabel 6 dan Tabel 7.

Tabel 6. Luas \& Persentase Curve Number Tahun 2008 di DAS Pamukkulu

\begin{tabular}{|c|c|c|c|c|c|c|c|c|c|}
\hline \multirow[t]{2}{*}{ No } & \multirow[t]{2}{*}{ Penutupan Lahan } & \multicolumn{2}{|c|}{$\begin{array}{l}\text { Luas Hidrologi Tanah } \\
(\mathrm{Ha})\end{array}$} & \multicolumn{2}{|c|}{$\begin{array}{l}\text { Persentase Hidrologi } \\
\text { Tanah (\%) }\end{array}$} & \multicolumn{2}{|c|}{ Nilai CN } & \multicolumn{2}{|c|}{ Komposit CN } \\
\hline & & A & $\mathrm{C}$ & A & $\mathrm{C}$ & $\mathrm{A}$ & $\mathrm{C}$ & A & $\mathrm{C}$ \\
\hline 1 & Hutan Sekunder & 1673.56 & & 4.22 & 0.00 & 36 & 73 & 151.89 & 0.00 \\
\hline 2 & Pertanian Lahan Kering & 690.66 & 3485.24 & 1.74 & 8.79 & 72 & 88 & 125.36 & 773.19 \\
\hline 3 & Pertanian Lahan Kering Campur Semak & 10713.16 & 1418.23 & 27.01 & 3.58 & 62 & 84 & 1674.49 & 300.33 \\
\hline 4 & Sawah & 4822.04 & 9958.16 & 12.16 & 25.10 & 61 & 81 & 741.54 & 2033.47 \\
\hline 5 & semak Belukar & 6469.91 & & 16.31 & 0.00 & 49 & 77 & 799.22 & 0.00 \\
\hline 6 & Tambak & 248.27 & 187.57 & 0.63 & 0.47 & 59 & 78 & 36.93 & 36.88 \\
\hline & Total Hidrologi Tanah & 24617.60 & 15049.20 & 62.07 & 37.94 & & & 3529.43 & 3143.87 \\
\hline & Total & 39666 & 6.80 & & & & & & \\
\hline & Nilai CN & & & & & & & & 6673.30 \\
\hline & CN Komposit & & & & & & & & 66.73 \\
\hline
\end{tabular}

Sumber : Analisis GIS, 2019

Tabel 7. Luas \& Persentase Curve Number Tahun 2017 di DAS Pamukkulu

\begin{tabular}{|c|c|c|c|c|c|c|c|c|c|}
\hline \multirow[t]{2}{*}{ No } & \multirow[t]{2}{*}{ Penutupan Lahan } & \multicolumn{2}{|c|}{$\begin{array}{l}\text { Luas Hidrologi Tanah } \\
\qquad(\mathrm{Ha})\end{array}$} & \multicolumn{2}{|c|}{$\begin{array}{c}\text { Persentase Hidrologi } \\
\text { Tanah (\%) }\end{array}$} & \multicolumn{2}{|c|}{ Nilai CN } & \multicolumn{2}{|c|}{ Komposit CN } \\
\hline & & $A$ & $\mathrm{C}$ & $A$ & $\mathrm{C}$ & A & $\mathrm{C}$ & A & $\mathrm{C}$ \\
\hline 1 & Hutan Sekunder & 1673.56 & 0.00 & 4.22 & 0.00 & 36 & 73 & 151.89 & 0.00 \\
\hline 2 & Permukiman & 262.13 & 643.78 & 0.66 & 1.62 & 51 & 79 & 33.70 & 128.21 \\
\hline 3 & Pertanian Lahan Kering & 1882.50 & 2824.11 & 4.75 & 7.12 & 72 & 88 & 341.70 & 626.52 \\
\hline 4 & Pertanian Lahan Kering Campur Semak & 9804.84 & 400.38 & 24.72 & 1.01 & 62 & 84 & 1532.52 & 84.79 \\
\hline 5 & Sawah & 4121.88 & 10988.23 & 10.39 & 27.70 & 61 & 81 & 633.87 & 2243.81 \\
\hline 6 & semak Belukar & 6565.78 & 0.00 & 16.55 & 0.00 & 49 & 77 & 811.06 & 0.00 \\
\hline 7 & Tambak & 306.93 & 192.69 & 0.77 & 0.49 & 59 & 78 & 45.65 & 37.89 \\
\hline & Total Hidrologi Tanah & 24617.62 & 15049.19 & 62.06 & 37.94 & & & 3550.39 & 3121.22 \\
\hline & Total & 3966 & 6.81 & & & & & & \\
\hline & Nilai CN & & & & & & & & 6671.61 \\
\hline & CN Komposit & & & & & & & & 66.72 \\
\hline
\end{tabular}

Sumber : Analisis GIS, 2019

Perbedaan nilai curve number retensi air pada penutupan lahan tahun (CN) penutupan lahan tahun 2008 dan 2017 lebih tinggi dari pada tahun 2008. tahun 2017 hanya sebesar 0,01 mm. Nilai retensi air menjadi masukan nilai Sedangkan perbedaan Retensi air (S) untuk memperoleh data volume penutupan lahan tahun 2008 dan tahun aliranpermukaan. Kondisi aliran 2017 sebesar 0,9 mm. Nilai $\mathrm{CN}$ dan permukaan kondisi curah hujan pada suatu 
wilayah. Adapun volume air permukaan Kondisi Air Permukaan Terhadap Curah pada DAS Pamukkulu pada Gambar 2 dan Hujan DAS Pamukkulu pada Gambar 3.

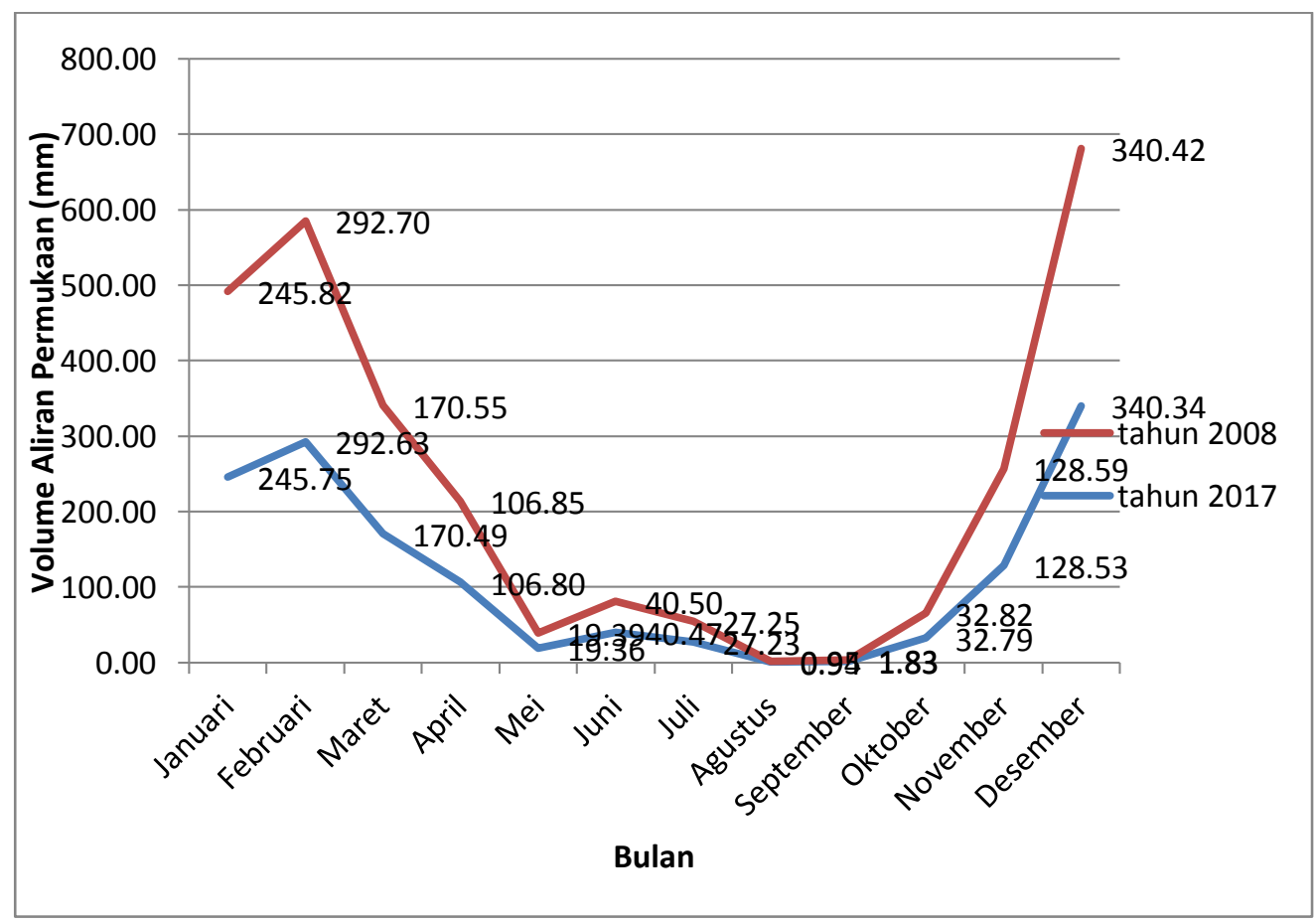

Gambar 2. Volume Aliran Permukaan

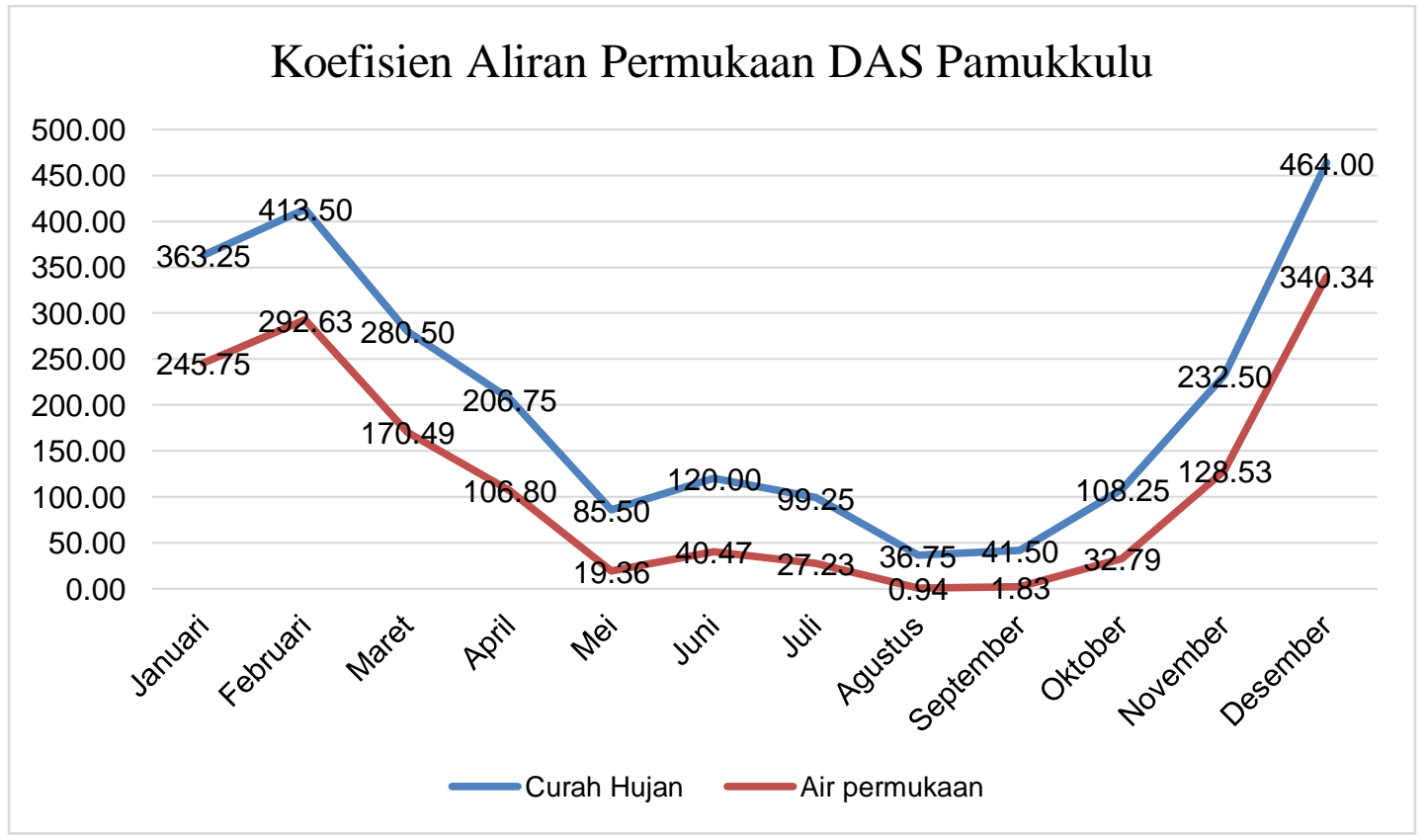

Gambar 3. Kondisi Air Permukaan Terhadap Curah Hujan DAS Pamukkulu 
Gambar diatas menunjukkan persentase pada bulan Desember dengan persentase volume aliran permukaan terhadap kondisi 73,35 persen. Sedangkan Persentase curah hujan di DAS Pamukkulu. Bahwa volume aliran permukaan terhadap curah semakin tinggi curah hujan setiap hujan terendah pada bulan Agustus bulannya maka persentase volume aliran dengan persentase 2,56 persen. Hal permukaan terhadap curah hujan semakin tersebut menunjukkan koefisien volume tinggi. Persentase volume aliran aliran permukaan dalam kondisi sedang. permukaan terhadap curah hujan tertinggi

\section{Koefisien Regim Sungai}

Tabel 8. Rekapitulasi Perhitungan Nilai KRS Tahun 2008 - 2017

\begin{tabular}{llllll}
\hline \hline NO & Tahun & $\begin{array}{c}\text { Debit Maksimum } \\
\left(\mathbf{m}^{3} / \mathbf{s}\right)\end{array}$ & $\begin{array}{c}\text { Debit Minimum } \\
\left(\mathbf{m}^{\mathbf{3}} / \mathbf{s}\right)\end{array}$ & KRS & \multicolumn{1}{c}{ Penilaian } \\
\hline 1 & 2017 & 29,67 & 0,25 & 119,6 & Buruk \\
2 & 2016 & 19,36 & 0,29 & 66,75 & Sedang \\
3 & 2015 & 42,25 & 0,29 & 144,31 & Buruk \\
4 & 2014 & 94,30 & 0,46 & 205,30 & Buruk \\
5 & 2011 & 10,32 & 0,15 & 70,01 & Sedang \\
6 & 2010 & 22,60 & 6,37 & 3,55 & Baik \\
7 & 2008 & 50,21 & 0,40 & 125 & Buruk \\
\hline \hline
\end{tabular}

Sumber : Hasil Analisis, 2019

Tabel di atas menunjukkan hasil perhitungan nilai KRS dari tahun 2008 sampai dengan tahun 2017, akan tetapi dikarenakan keterbatasan data tidak ditemukan data debit tahun 2013, 2012, dan 2009. Nilai rata-rata Koefisien Regim Sungai pada DAS Pamukkulu berdasarkan hasil perhitungan sebesar 428 yang termasuk dalam klasifikasi buruk. masuk ke sungai dan terbuang ke laut. koefisien regim sungai dapat dilihat Sedangkan pada bulan dengan musim bahwa nilai koefisien regim sungai kemarau terjadi nilai limpasan yang terendah yaitu pada tahun 2010 sebesar sangat kecil yang mengakibatkan semakin
3,55 sedangkan nilai koefisien regim sungai tertinggi yaitu pada tahun 2014 sebesar 205,30 yang menunjukkan bahwa nilai limpasan pada saat bulan musim penghujan terjadi sangat besar dan kondisi lahan yang berada di daerah DAS Pamukkulu kurang mampu menyerap air yang mengalir sehingga air limpasan$$
\text { secil yang mengakibatkan semaki }
$$ 
lama debit air yang berada di daerah DAS Pamukkulu semakin menipis.

Nilai KRS sangat dipengaruhi oleh selisih antara nilai debit maksimum dan minimum. Pada tahun 2014 debit minimum rata-rata bulanan hanya $0,46 \mathrm{~m}^{3} / \mathrm{s}$ sedangkandebit maksimum mencapai $94,30 \mathrm{~m}^{3} / \mathrm{s}$. Tabel hasil pengukuran data debit dapat dilihat pada Lampiran 1 sampai Lampiran Pengukuran debit pada tahun 2008 dapat dikatakan tidak lengkap, dikarenakan terdapat data yang kosong atau tidak dilakukan pengukuran. Data kosong tersebut mempengaruhi rata-rata debit dan nilai debit maksimum maupun debit minimum yang dihasilkan.

\section{Koefisien Varian (CV)}

Hasil Perhitungan nilai koefisien varian diperoleh dari pembagian antara nilai standar deviasi debit dengan debit ratarata dikali seratus persen. Rekapitulasi perhitungan nilai koefisien varian serta klasifikasi nilai koefisien varian tahun 2008 sampai tahun 2017 dapat dilihat pada Tabel 9.

Tabel 9. Perhitungan dan Klasifikasi Koefisien Varian (CV)

\begin{tabular}{llllll}
\hline \hline No & Tahun & Standar Deviasi & Qrata-rata & $\begin{array}{l}\text { Koefisien } \\
\text { Variant }(\mathbf{C V}) \\
(\boldsymbol{\%})\end{array}$ & Penilaian \\
\hline \hline 1 & 2017 & 10,59 & 12,15 & 87,15 & Buruk \\
2 & 2016 & 5,67 & 10,79 & 52,56 & Buruk \\
3 & 2015 & 13,53 & 11,58 & 116,75 & Buruk \\
4 & 2014 & 26,11 & 23,94 & 109,05 & Buruk \\
5 & 2011 & 4,08 & 3,81 & 107,01 & Buruk \\
6 & 2010 & 5,88 & 13,29 & 44,24 & Buruk \\
7 & 2008 & 14,89 & 10,28 & 144,90 & Buruk \\
\hline
\end{tabular}

Berdasarkan Tabel 17 nilai ratarata koefisien varian dari tahun 2008 2017 sebesar 94,57\%, merujuk pada klasifikasi penilaian koefisien varian termasuk ke dalam kondisi kelas penilaian buruk. variasi antara debit maksimum dan debit minimum yang terjadi pada tahun 2008 sampai tahun 2017 banyak mengalami perubahan. Hal ini disebabkan karena perbandingan jarak antara debit maksimum pada saat musim penghujan yang terjadi di Bulan Oktober sampai dengan bulan Desember dengan debit minimum pada musim kemarau yang terjadi di Bulan Juli sampai Bulan 
September mengalami perubahan debit DAS (catchment health) bersangkutan yang cukup besar.

\section{Tingkat Kesehatan DAS}

DAS sebagai suatu ekosistem pada sistem pengelolaan yang diterapkan dapat dipandang sebagai merupakan satuan monitoring dan kegiatan diagnose.

evaluasi (monev) karena setiap ada

Berdasarkan metode penentuan masukan (input) ke dalam ekosistem tersebut dapat dievaluasi proses yang telah dan sedang berlangsung dengan melihat keluaran (output) dari ekosistem tersebut. Wilayah DAS yang terdiri dari komponen tanah, vegetasi dan kesehatan DAS yang digunakan dalam penelitian ini yaitu menyimpulkan dari hasil analisis Indeks penutupan lahan tahun 2008 dan 2017 dan kondisi hidrologi berdasarkan Koefisien Aliran Permukaan (c), Koefisien Regim Sungai air/sungai berperan sebagai prosesor. dapat terlihat pada Tabel 10 sebagai Kegiatan monev yang menghasilkan berikut:

informasi tentang tingkat kesehatan

Tabel 10. Perubahan IPL, CN, CV, dan KRS DAS Pamukkulu Tahun 2008 dan 2017

\begin{tabular}{|c|c|c|c|c|}
\hline \multirow{2}{*}{ Tahun } & \multirow{2}{*}{$\begin{array}{l}\text { Indeks Penutupan Lahan } \\
\text { (IPL) }\end{array}$} & \multicolumn{3}{|c|}{ Analisis Debit Sungai DAS Pamukkulu } \\
\hline & & $\mathrm{CN}$ & KRS & $\mathrm{CV}$ \\
\hline 2008 & $19.38 \%$ & 6673.30 & 125 & $144.90 \%$ \\
\hline 2017 & $16.96 \%$ & 6671.60 & 119.6 & $87.15 \%$ \\
\hline
\end{tabular}

Sumber : Hasil Analisis, 2019

Hasil analisis Indeks Penutupan Lahan (IPL) menerangkan bahwa kondisi Penutupan lahan DAS Pamukkulu tahun 2008 berada pada angka 19,38\% dan $16,96 \%$ pada tahun 2017. Berdasarkan klasifikasi IPL dimana apabila nilai IPL $<30 \%$ dapat dikategorikan buruk. CV > 10\% maka dikategorikan jelek. Sementara hasil analisis hidrologi (debit Berdasarkan hasil analisis dari nilai air sungai) pada Koefisien Regim Sungai Indeks Penutupan Lahan, Koefisien tahun 2008 sebesar 125 dan tahun 2017 sebesar 119,6 dimana nilai KRS > 120 sehingga dikategorikan buruk. Sedangkan dari hasil analisis Koefisien Varian (CV) pada tahun 2008 sebesar 144,90\% dan tahun 2017 sebesar 87,5\% dimana nilai 
Regim Sungai dan Koefisien Regim Sungai pada DAS Pamukkulu pada tahun 2008 dan 2017 yang berada pada kategori buruk maka kinerja DAS Pamukkulu berada dalam kategori buruk.

\section{KESIMPULAN DAN SARAN}

\section{Kesimpulan}

Adapun kesimpulan dari hasil penelitian ini adalah sebagai berikut :

1. Luas Vegetasi Permanen pada DAS Pamukkulu tahun 2008 sebanyak 7739, 26 Ha dengan Indeks Penutupan Lahan sebesar 19,38\% sedangankan Luas Tutupan Lahan pada DAS Pamukkulu tahun 2017 sebanyak 6776,17 Ha dengan Indeks Penutupan Lahan sebesar $16,96 \%$.

2. Terjadi penurunan fluktuasi debit sungai utama di DAS Pamukkulu dimana nilai KRS sebesar 119,6, nilai $\mathrm{CN}$ sebesar 6671,60 dan nilai $\mathrm{CV}$ sebesar $87,15 \%$ pada tahun 2017 akibat terjadinya perubahan penutupan lahan di tahun 2017 dibandingkan dengan tahun 2008 dimana nilai KRS sebesar 125 , nilai CN sebesar 6673,30 dan nilai CV sebesar $144,90 \%$.

3. Berdasarkan nilai Indeks Penutupan Lahan (IPL) Tahun 2008 dan Tahun 2017 kurang dari 30\%, Koefisien
Regim Sungai (KRS) Tahun 2008 dan

Tahun 2017 besar dari 120 dan Koefisien Variant (CV) Tahun 2008 dan 2017 besar dari 10\% maka Tingkat Kesehatan DAS Pamukkulu dikategorikan buruk.

\section{Saran}

Setelah melaksanakan penelitian ini, maka penulis dapat menyarankan hal-hal sebagai berikut :

1. Melakukan upaya rehabilitasi lahan utamanya di wilayah DAS Pamukkulu yang mengalami perubahan penutupan lahan (Kecamatan Bungaya dan Polombangkeng Utara) demikian pula dengan Kecamatan yang penutupan lahannya belum memenuhi penutupan lahan minimal 30\% dari luas wilayah. Hal tersebut dilaksanakan demi kepentingan masyarakat yang bermukim di wilayah DAS Ds dalam pemenuhan kebutuhan air di musim kemarau dan untuk menghindari terjadinya bencana banjir di musim hujan.

2. Dihimbau kepada Pemerintah Kabupaten Gowa, Takalar dan Jeneponto dalam melaksanakan pembangunan agar lebih sensitif terhadap lingkungan dan 
memperhatikan keseimbangan antara

pembangunan sosial, ekonomi dan ekologi utamanya dalam penganggaran biaya rehabilitasi dan konservasi lahan kritis, sehingga kerusakan yang terjadi di DAS Pamukkulu dapat diperbaiki dan minimal dapat di perlambat.

3. Disarankan agar pembangunan di Kabupaten Gowa, Takalar dan Jeneponto di selaraskan dengan rencana yang tertuang dalam Perda Provinsi Sulawesi Selatan Nomor 9 Tahun 2009 tentang Rencana Tata Ruang Wilayah Provinsi Sulawesi Selatan.

\section{DAFTAR PUSTAKA}

Baja, S. 2012. Perencanaan Tata Guna Lahan dalam Pengembangan Wilayah. Unhas, Makassar.
Departemen Kehutanan, 2009. Peraturan Direktur Jenderal Rehabilitasi Lahan dan Perhutanan Sosial Nomor : P.04/V.Set/2009 tentang Pedoman Monitoring dan Evaluasi DAS, Jakarta.

Diana, A.R, 2008. Kajian Perubahan Penutupan Lahan di Kawasan Pesisir Kabupaten Aceh Utara. Bogor; IPB.

Dinas Pengelolaan Sumber Daya Air, 2017. Laporan Tahunan 2017, Makassar.

Ditjen RLPS. 2007. Pedoman Pemantauan Tata Air Daerah Aliran Sungai dengan Pendekatan Model Hidrologi. Jakarta: Direktorat Jenderal Reboisasi dan Rahabilitasi Lahan, Departemen Kehutanan.

Kementerian Lingkungan Hidup dan Kehutanan, 2017. Laporan Kinerja Kementerian Ligkugan Hidup dan Kehutanan Tahun 2017, Jakarta.

Wahyunto, 2001. Studi Perubahan Lahan di Sub DAS Citarik Jawa Barat dan Kali. Universitas Padjadjaran, Jawa Barat. 